\title{
HORIZONTAL PRESSURES IN CYLINDRICAL METAL SILOS AND COMPARISON WITH DIFFERENT INTERNATIONAL STANDARDS
}

\section{JOSÉ W. B. DO NASCIMENTO ${ }^{1}$, JOSÉ P. LOPES NETO ${ }^{2}$, MICHAEL D. MONTROSS ${ }^{3}$}

\begin{abstract}
The focus of this research was to evaluate the horizontal pressures on a cylindrical metal silo of corrugated walls and flat bottom with $1.82 \mathrm{~m}$ diameter and $5.4 \mathrm{~m}$ high, and to compare the values with those obtained theoretically by the ISO 11697, EP 433 and AS 3774 standards. The silo was symmetrically filled and constant speed with wheat $c v$. soft red for two different height/diameter ratios (H/D) and was unloaded through three orifices with a diameter of $71.6 \mathrm{~mm}$, one concentric and two eccentrics. Horizontal pressures were measured on the walls of the silo at three positions using hydraulic type pressure cells. The results showed that shortly after the start of the unloading, there was a mass flow above the quota of $\mathrm{H} / \mathrm{D}=1.2$, whereas below this quota funnel flow occurred. It can be said that the EP 433 standard was more appropriate to predict horizontal pressures in silos in H/D ratio $=1.0$, with eccentric unloading. For the H/D ratio $=1.5$, AS 3774 standard was the one that produced values closer to the experimental.
\end{abstract}

KEYWORDS: horizontal pressures in silos, eccentric unloading, mixed flow.

\section{PRESSÕES HORIZONTAIS EM SILOS METÁLICOS CILÍNDRICOS E COMPARAÇÃO COM DIFERENTES NORMAS INTERNACIONAIS}

RESUMO: Objetivou-se com este trabalho avaliar as pressões horizontais em um silo metálico cilíndrico de paredes corrugadas e fundo plano com 1,82 m de diâmetro e 5,4 m de altura, e comparar os valores com os obtidos teoricamente pelas normas ISO 11697, EP 433 e AS 3774. O silo foi carregado de forma simétrica e velocidade constante com trigo $\mathrm{cv}$. soft red para duas diferentes relações de altura/diâmetro (H/D) e descarregado através de três orifícios com diâmetro de 71,6 mm, sendo um concêntrico e dois excêntricos. As pressões horizontais foram medidas nas paredes do silo, em três posições, utilizando-se de células de pressão tipo hidráulica. Os resultados mostraram que logo após o início da descarga ocorreu fluxo de massa acima da cota de H/D = 1,2, enquanto abaixo desta cota se observou fluxo de funil. Pode-se afirmar que a norma EP 433 se mostrou mais adequada para predizer as pressões horizontais em silos com relação H/D =1,0 com descargas excêntricas. Para a relação H/D = 1,5, a norma AS 3774 foi a que produziu valores mais próximos aos experimentais.

PALAVRAS-CHAVE: pressão horizontal em silos, descarga excêntrica, fluxo misto.

\section{INTRODUCTION}

With the increasing global industrialization, the use of silos has become important, because it represents the possibility of storage of products originating in the industries of spinning, mining, construction, food, pharmaceutical, among other. In this aspect, functionality problems, such as obstructions in the flow, tube effect and incomplete unloading became more frequent, while structural problems became responsible for many accidents resulting in loss of life and enormous economic damage.

\footnotetext{
${ }^{1}$ Associate Professor, Department of Agricultural Engineering, Federal University of Campina Grande, Campina Grande, Paraíba, Brazil. E-mail: wallace@deag.ufcg.edu.br.

${ }^{2}$ Associate Professor, Department of Agricultural Engineering, Federal University of Campina Grande, Campina Grande, Paraíba, Brazil. E-mail: lopesneto@deag.ufcg.edu.br.

${ }^{3}$ Associate Professor, Department of Biosystems and Agricultural Engineering, University of Kentucky, Lexington, Kentucky, USA. E-mail: michael.montross@uky.edu.

Recebido pelo Conselho Editorial em: 9-10-2012
}

Aprovado pelo Conselho Editorial em: 13-12-2013 
With the emergence of a range of new storable industrial products, it is extremely important that the type of flow developed for these products is known, in order to establish, securely, the most suitable conditions of transportation, storage and handling (LOPES NETO et al., 2009a).

According to WÓJCIK et al. (2012), knowing the flow pattern occurring in the silos is essential to predict the pressures acting on its walls and bottom, noting that the pressure on the walls during the unloading are higher than during loading.

According to MARQUES NETO \& SILVA (2011), the main actions that comprise the loading on the silo are their own and equipment weight, pressure and friction forces caused by stored product, effect of wind and temperature variation, considering that the effect of these actions may cause from local buckling to the complete disruption of the structure.

According to ROTTER \& SADOWSKI (2012), the pressures present in the silos for different patterns and asymmetrical loads, and, in the case of silos with eccentric unloading, pressures tend to be higher on the side opposite to the unloading orifice. Thus, it was decided to install pressure cells diametrically opposed to the unloading orifices.

According to GALLEGO et al. (2011), Southern bending moments may occur in silos with eccentric unloading and subject to compressive axial loads and tend to grow linearly with increasing depth of silo.

Knowledge and measuring of these actions are somewhat complex due to the large interaction between variables involved in various possible situations and also to the lack of information about sensors and equipment designed for such measurements.

According to RAMÍREZ et al. (2010a), pressure cells may be used satisfactorily on the knowledge of pressure distribution on the silo walls, whose few cells of pressure are based on the displacement of a piston drive, plate bending, or by load transfer by fluid medium.

Several theoretical models were developed to predict the behavior of the products stored in silos, and we may mentioned those developed by ARTONI et al. (2009), MATCHETT et al. (2008) VIDAL et al. (2008), but such models require validation through experimental tests, whose procedures are difficult to perform due to the high costs involved. In addition, many of the parameters of the product stored required by these theoretical models have not been sufficiently analyzed.

JULIANO et al. (2006) state that the determination of the flow properties of storable products is important, because it helps in understanding the behavior of storable products in silos, hoppers and conveyors, and it is possible to maximize the unloading operations and avoid uncertainties as to the type of flow and obstructions of unloading. Another importance of its knowledge is in fact that its values are employed in the theories of pressures adopted by the standards chosen for this research.

Several studies, including those cited by the LOPES NETO (2009), SAFARIAN and HARRIS (1985), and LOPES NETO et al. (2008), show that there is no consensus by researchers and standards regarding the classification of silos with respect to the height/diameter ratio (H/D), being RAVENET (1992) one of the earliest studies taking into account such a ratio.

The objective of this study was to determine experimentally the horizontal pressures on a vertical metal silo of corrugated wall with two height/diameter ratios (H/D) combined with one symmetric unloading and two asymmetric unloading using grains of wheat, and comparing the results with the pressures obtained by ISO 11697 (1995), EP 433 (2000) and AS 3774 (1996).

\section{MATERIAL AND METHODS}

This study was performed at the Laboratory of Biosystems Engineering, University of Kentucky, Lexington - USA, located at latitude $38^{\circ} 02^{\prime}$ ' N, longitude $84^{\circ} 36^{\prime}$ ' W and altitude of $718 \mathrm{~m}$. The tests were performed in a flat bottom silo of galvanized steel corrugated wall of $1.82 \mathrm{~m}$ diameter 
and $5.9 \mathrm{~m}$ high, and the pitch and depth of the corrugated walls were of $67.5 \mathrm{~mm}$ and $13 \mathrm{~mm}$, respectively.

The unloading openings were formed by a concentric $\left(E_{0}\right)$ and two eccentric orifices with a diameter of $71.7 \mathrm{~mm}$ for each orifice. The eccentricities $E_{1}$ and $E_{2}$ of the eccentric orifices were equal to 0.33 and 0.91 (dimensionless), respectively, of the ration between the distance of the center of the unloading orifice and to the silo axis and the value of the silo radius.

For the measurements of the side pressure on the silo wall, it was installed three pressure cells (CP), hydraulic type - EPC 3500-1-100, GEOKON model, on the side diametrically opposite the eccentric unloading orifices in order to record the pressures caused by the formation of the slope of grains along its unloading, Figure 1.

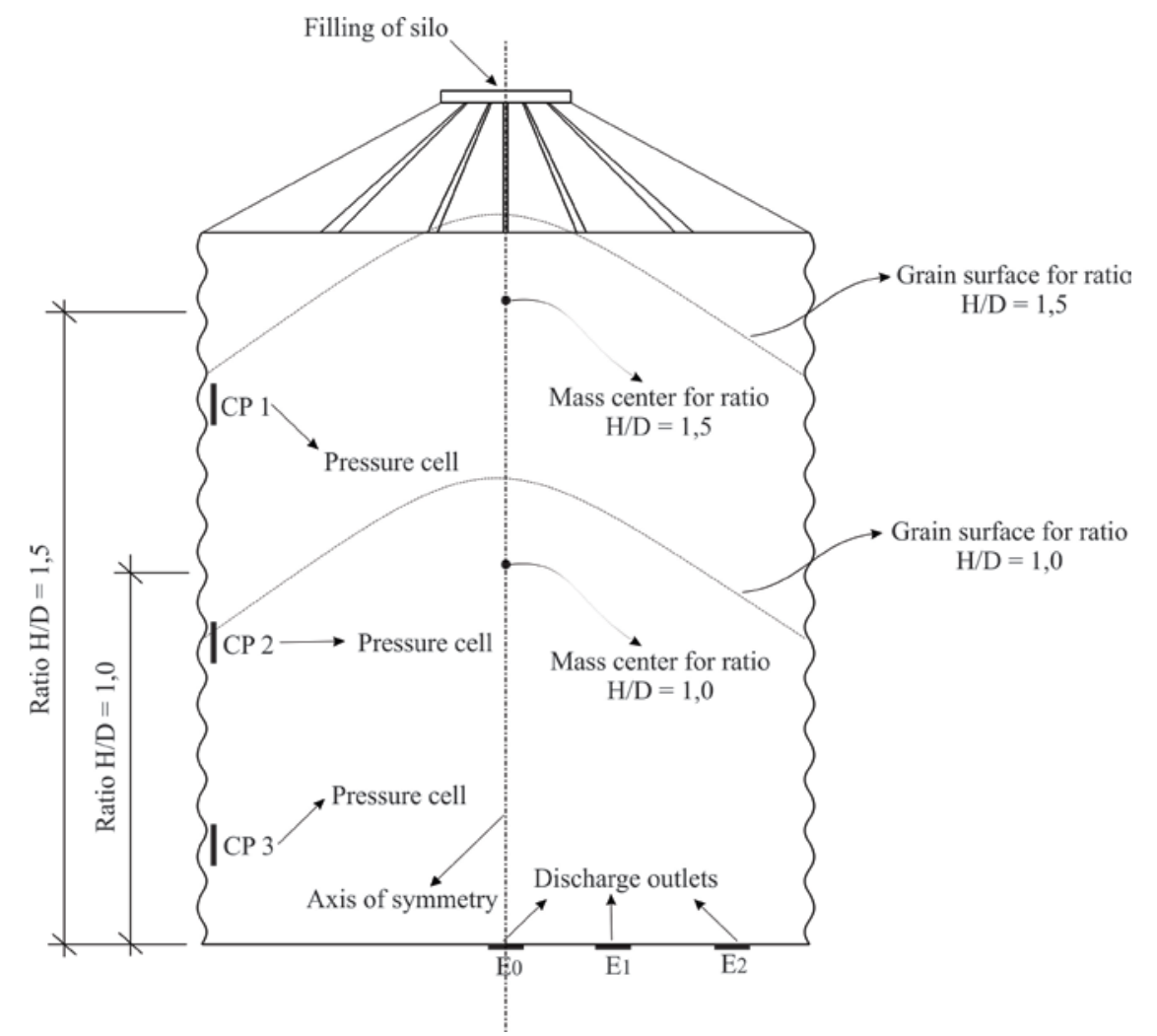

FIGURE 1. H/D ratio and layout of the instrumentation.

The loading happened concentrically at a speed of sliding of the grains on the wall of about $0.12 \mathrm{~m} / \mathrm{min}$, leaving the grain mass to stand for one hour (1h) for the purpose of accommodating the stresses of loading, and then the unloading was performed.

The grain used for the determination of pressures and model validation was the wheat cultivar Soft Red, whose flow properties were determined in the laboratory by following the procedures described in LOPES NETO et al. (2009b), using the translational shear apparatus (TSG - 70/140 model, Zeppelin Manufacturer), and the shear cell known as Jenike Shear Cell.

In this study, it was adopted the range $1.0 \leq \mathrm{H} / \mathrm{D} \leq 1.5$, because they are two ranges of conflict between the standards studied with representing tests to the use of two (2) silos classified as intermediate with height/diameter ratios (H/D) equal to 1.0 and 1.5. For each test of loading and unloading in the two pre-defined loading (H/D equal to 1.0 and 1.5) and unloading (concentric orifice $\mathrm{E}_{0}$ and two eccentric orifices $\mathrm{E}_{1}$ and $\mathrm{E}_{2}$ ) conditions, it was evaluated with three replicates, i.e., at the end of the tests is as the silo had been loaded and unloaded 18 consecutive times.

It was also compared the lateral pressures obtained experimentally and the pressures calculated by the ISO 11697 (1995), EP 433 (2000) and AS 3774 (1996) models, to identify which model best fits the data obtained. 
Basically all international standards are used in the same expression for the estimation of horizontal loading pressures, equation (1), differing only for unloading the adoption of different coefficients of overpressure.

$$
P_{h e}=\frac{\gamma R}{\mu} C_{z}(Z)
$$

In which,

$\mathrm{P}_{\mathrm{hc}}$ - horizontal loading pressure, $\mathrm{Pa}$;

$\gamma$ - specific consolidated weight, $\mathrm{N} / \mathrm{m}^{3}$;

$\mathrm{R}$ - hydraulic radius, $\mathrm{m}$, and

$\mu$ - coefficient of friction of the product with the wall, dimensionless

The $C_{z}(Z)$ factor is given by the following equation:

$$
C_{z}(Z)=1-e^{\left(\frac{z k \mu}{R}\right)}
$$

In which,

$\mathrm{k}$ - ratio between vertical and horizontal pressure, and

$\mathrm{z}$ - silo depth, $\mathrm{m}$

The theoretical values of overpressure were obtained by multiplying the coefficients of overpressure to loading pressures. To ISO 11697 (1995) standard, overpressure coefficients are defined as equal to 1.0 and $1.0+0.7(\mathrm{H} / \mathrm{D}-1.0)$ to ratios $\mathrm{H} / \mathrm{D}=1.0$ and 1.5 , respectively.

The EP 344 (2000) standard recommends an additional of $40 \%$ in the horizontal unloading pressure for the product and silo tested in this research. As for the AS 3774 (1996) standard, it recommends using the higher value of the equations (3) and (4), hereafter:

$$
\begin{aligned}
& C=\left[7,6(H / D)^{0,06}-6,4\right] C c \\
& C=1.2 \text { Cc }
\end{aligned}
$$

In which,

Cc - geometry coefficient of the flow equal to 1.0 for asymmetric flow and 1.2 for plan flow.

\section{RESULTS AND DISCUSSION}

According to the AS 3774 (1996) standard, the wheat in grains has specific consolidated weight $(\gamma)$ ranging between 7.5 and $9.0 \mathrm{kN} \mathrm{m}^{-3}$, effective internal friction angle $(\delta)$ ranging between 26 and $32^{\circ}$. Under the storage conditions of silo with plain steel wall $\left(\varnothing_{\mathrm{w}}\right)$, the value recommended by AS 3774 (1996) for the friction angle is between 18 and 30. As for ISO 11697 (1995), it fixes to wheat grains a value of specific consolidated weight $(\gamma)$, effective internal friction angle $(\delta)$ and friction angle of the product with the wall $\left(\varnothing_{\mathrm{w}}\right)$ equal to $8.5 \mathrm{kN} \cdot \mathrm{m}^{-3}, 27^{\circ}$ and $16.7^{\circ}$, respectively.

In measurements performed in the laboratory for wheat grains cv. Soft Red used in the tests, it was obtained the following properties: specific consolidated weight $\gamma$ of $8.3 \mathrm{kN} . \mathrm{m}^{-3}$, effective internal friction angle $\delta$ of $36^{\circ}$, and friction angle of wheat with the wall $\varnothing_{w}$ of $18.8^{\circ}$. The value of the specific consolidated weight $(\gamma)$ was compatible with the recommended by the studied standards, however, for the angle of friction of the product with the wall $\left(\varnothing_{w}\right)$, the value fixed by ISO 11697 (1995) presented itself below the experimentally determined.

It may be noted that the greatest difference was found for the effective internal friction angle ( $\delta$ ), which is $20 \%$ and $33 \%$ higher than the maximum limits proposed by AS 3774 (1996) and ISO 11697 (1995), respectively, and these differences may be a result of physical characteristics such as size, shape and specific consolidated weight inherent to each wheat cultivar.

It may be found in Figure 2 the curves of horizontal pressures of concentric loading and unloading with H/D ratio equal to 1.0 , where we can observe that the values of the experimental 
horizontal pressures of loading are lower than the calculated by the studied standards, and AS 3774 (1996) was the best fit to the experimental data, while EP 433 (2000) adjusted perfectly to pressures of unloading, even if in its formulation there is no recommendation to use overpressure coefficient.

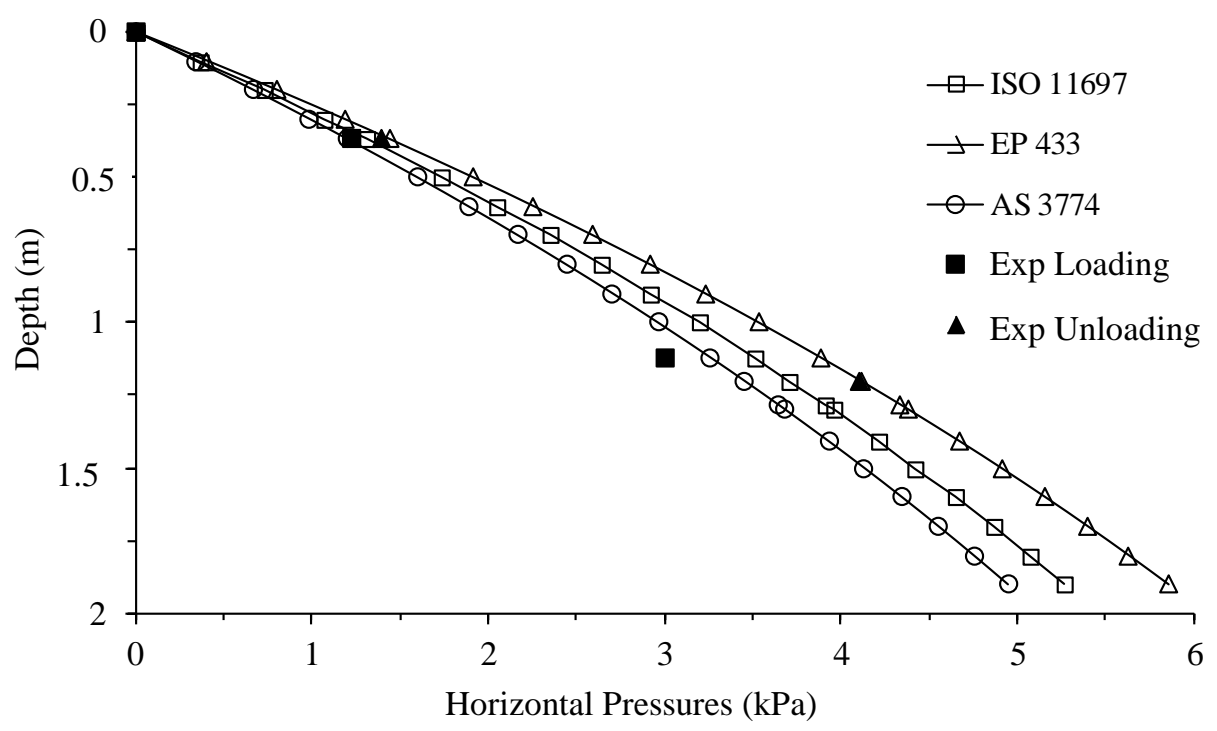

FIGURE 2. Horizontal pressures in the silo with $\mathrm{H} / \mathrm{D}=1.0$ and concentric unloading.

To this ratio of H/D, it was considered that there would be no overpressure coefficient for unloading, as recommended by the standards, but it was experimentally observed that there is an increase in horizontal pressure during the beginning of unloading at the top and bottom of the silo of $19 \%$ and $36 \%$, respectively.

The pressure cell CP3, located at the bottom of the silo, was close to the contour of the cone formed by the static grain at the silo bottom, while the pressure cell of the top (CP2) was on the limit of the contour of the upper cone of the grain mass. Thus, it is considered that CP3 would better represent the pressure status around the point that the natural slope intercepted the wall of the silo during the beginning of unloading.

DINIZ and NASCIMENTO (2006) have built, instrumented and measured horizontal pressures in a cylindrical silo of reinforced masonry with ratio $\mathrm{H} / \mathrm{D}=1.0$, whose maximum values were obtained for the loading phase equals $4 \mathrm{kPa}$, a value compatible only with unloading phase of this research for the same ratio. As factors that might explain the same pressure for different stages of loading and unloading between the two studies, we may enumerate, mainly, the different specific weight between the products of the two studies and the eccentricity of loading existing on the research of Diniz and Nascimento (2006).

For the eccentric unloading $\mathrm{E}_{1}$ in the silo with $\mathrm{H} / \mathrm{D}=1.0$ (Figure 3), standard EP 433 (2000) the behavior was considered as the most suitable of the three standards, overestimating the experimental values at the position of CP2 of 21\%, while the ISO 11697 (1995) was the one that best adjusted to the value obtained by CP3. For the other two standards, the theoretical values were above the experimental of the depths the cells CP2 and CP3 were in. 


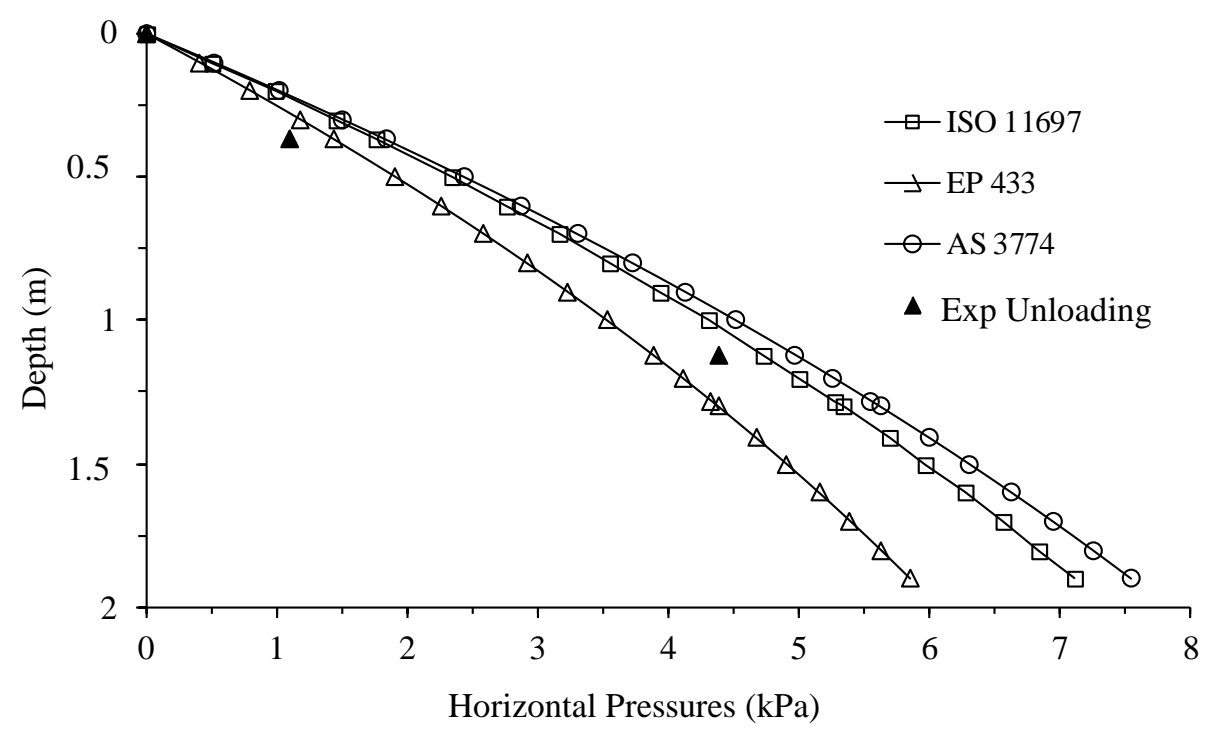

FIGURE 3. Pressures to the silo with $\mathrm{H} / \mathrm{D}=1.0$ and eccentric unloading of 0.33 .

It is noteworthy, however, that the horizontal pressure of unloading for $\mathrm{E}_{1}$ in depth CP3 was lower to the one measured on the concentric unloading $\left(\mathrm{E}_{0}\right)$, and this fact is due to the type of flow for this $\mathrm{H} / \mathrm{D}$ ratio and eccentricity $\left(\mathrm{E}_{1}=0.33\right)$ is typically of funnel and the CP3 stay in contact with the grain mass below the point where the grain slope intercepted the silo wall, while in the unloading symmetric $\left(E_{0}\right)$, the cell was located near the intercept point of the slope on the wall.

For eccentricity $E_{2}(0.91)$ in the same ratio $H / D=1.0$ (Figure 4), it is clear that the three (3) standards overestimated the experimental horizontal pressures, and the standard EP 433 (2000), even with its specificity, was the one that best adjusted to the experimental data, overestimating them in approximately 5\%. Considering that the agricultural grains vary in time and space inside the silo, this percentage may be considered normal, given that it is within the standard deviation since each horizontal pressure value is the average of three repetitions.

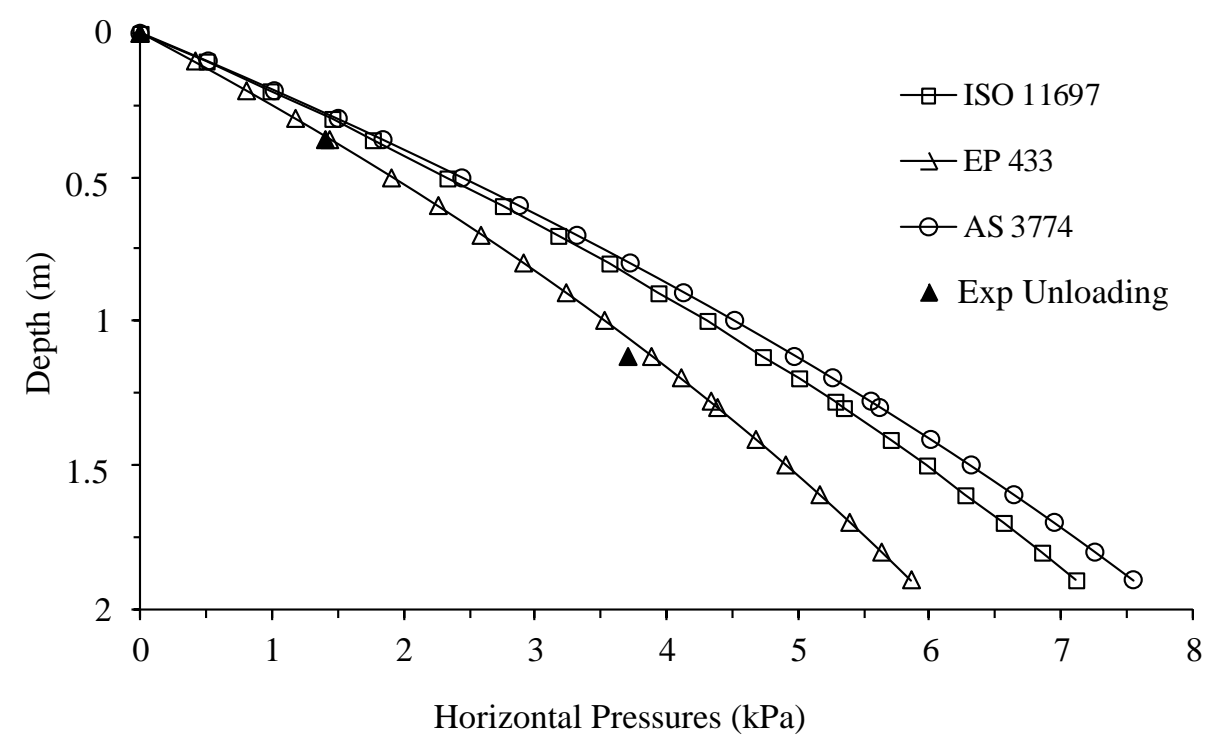

FIGURE 4. Pressures to the silo with $\mathrm{H} / \mathrm{D}=1.0$ and eccentric unloading of 0.91 .

Figures $5 \mathrm{a}$ and $5 \mathrm{~b}$ show the curves of horizontal pressures of concentric loading and unloading, respectively, in the silo with ratio $\mathrm{H} / \mathrm{D}=1.5$. It was found that both the loading and unloading pressures determined experimentally were lower than the values calculated by the standards used for comparison. However, it was observed increase of pressure on the walls during unloading in relation to the loading with coefficients of 1.2 and 1.36 for CP2 and CP3, respectively. 

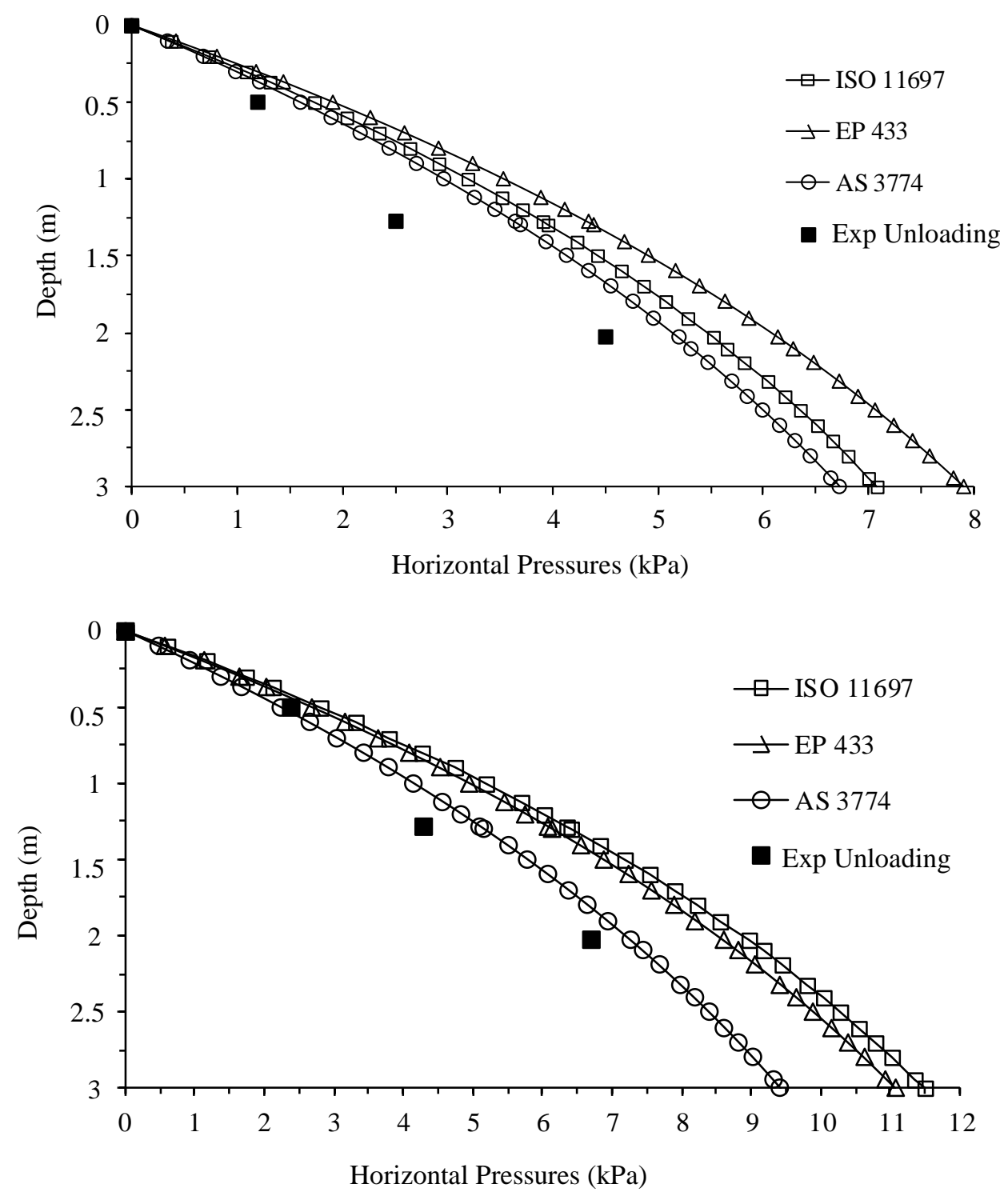

B

FIGURE 5. Horizontal pressures in silos with $\mathrm{H} / \mathrm{D}=1.5$ and concentric unloading $\left(\mathrm{E}_{0}\right)$. (A) Loading (B) Unloading.

The horizontal pressure of loading, Figure 5A, calculated by AS 3774 (1996) at a depth equivalent to the installation of CP3 overestimated by $15 \%$ the experimentally determined, while the EP 433 (2000) and ISO 11697 (1995) standards showed higher values of order of 22 and 36\%, respectively.

In Figure 5B, it is observed that the pressures calculated by the EP 433 (2000) and ISO 11697 (1995) standards overestimated horizontal pressures in 28 and 33\%, respectively, at the point where it was attached to CP3. It was also observed that the horizontal pressure curve provided by AS 3774 (1996) was very close to the experimental values, with a mean difference of approximately $8 \%$.

The importance of evaluating the silo actions from the H/D ratio may be demonstrated when comparing the values of unloading for the ratio $\mathrm{H} / \mathrm{D}=1.5$ (Figure $5 \mathrm{~B}$ ) with studies conducted by RAMÍREZ et al. (2010b), who obtained the same mean values during loading of wheat grains in a cylindrical metal silo with ratio $\mathrm{H} / \mathrm{D}=2.5$. This comparison shows that the pressure level in a ratio for the unloading may be the same as for the loading with simple changing of the H/D ratio.

For the eccentric unloading $\mathrm{E}_{1}=0.33$ (Figure 6), it was also noted that the standards used overestimated the horizontal pressure values immediately after the start of unloading, which were measured during the first 70 seconds with a frequency of $1 \mathrm{~Hz}$. Among the three standards adopted, 
the one that least overestimated the experimental values was AS 3774 (1996) with 21 and 13\% for the horizontal pressures equivalent to $\mathrm{CP} 2$ and $\mathrm{CP} 3$, respectively.

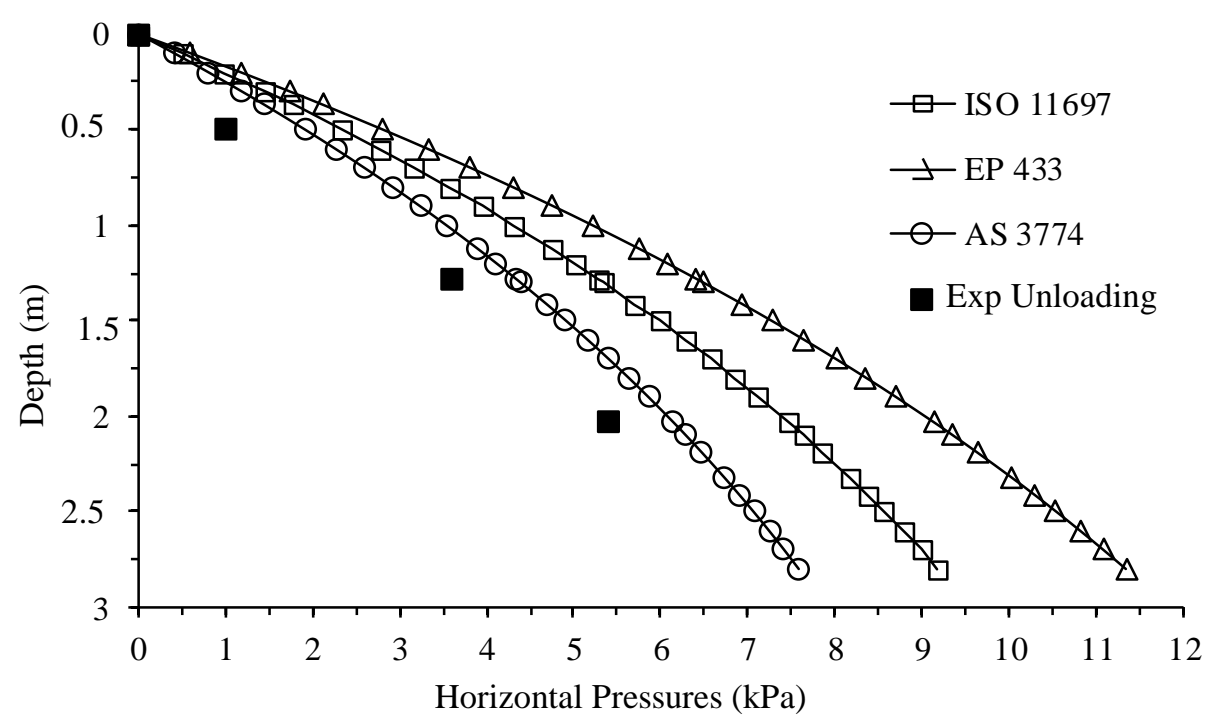

FIGURE 6. Horizontal pressures in silos with $\mathrm{H} / \mathrm{D}=1.5$ and eccentric unloading $\left(\mathrm{E}_{1}\right)$.

The grain slope intercepted the silo wall around H/D $=0.53$ and these probably had the greatest horizontal pressures acting on the wall. Even so, they were lower than those calculated by the standards, including the values of EP 433 (2000), which is unique to vertical silo with symmetric unloading.

For the silo with ratio $\mathrm{H} / \mathrm{D}=1.5$ and eccentricity $\mathrm{E}_{2}=0.91$ (Figure 7 ), the pressures calculated by ISO 11697 (1995) and EP 433 (2000) standards were lower than the experimental. For this H/D ratio, the AS 3774 (1996) standard was the one that most adjusted, because this standard proposed an equation to calculate the overpressure coefficient based on the H/D ratio, which results in theoretical values very close the experimental.

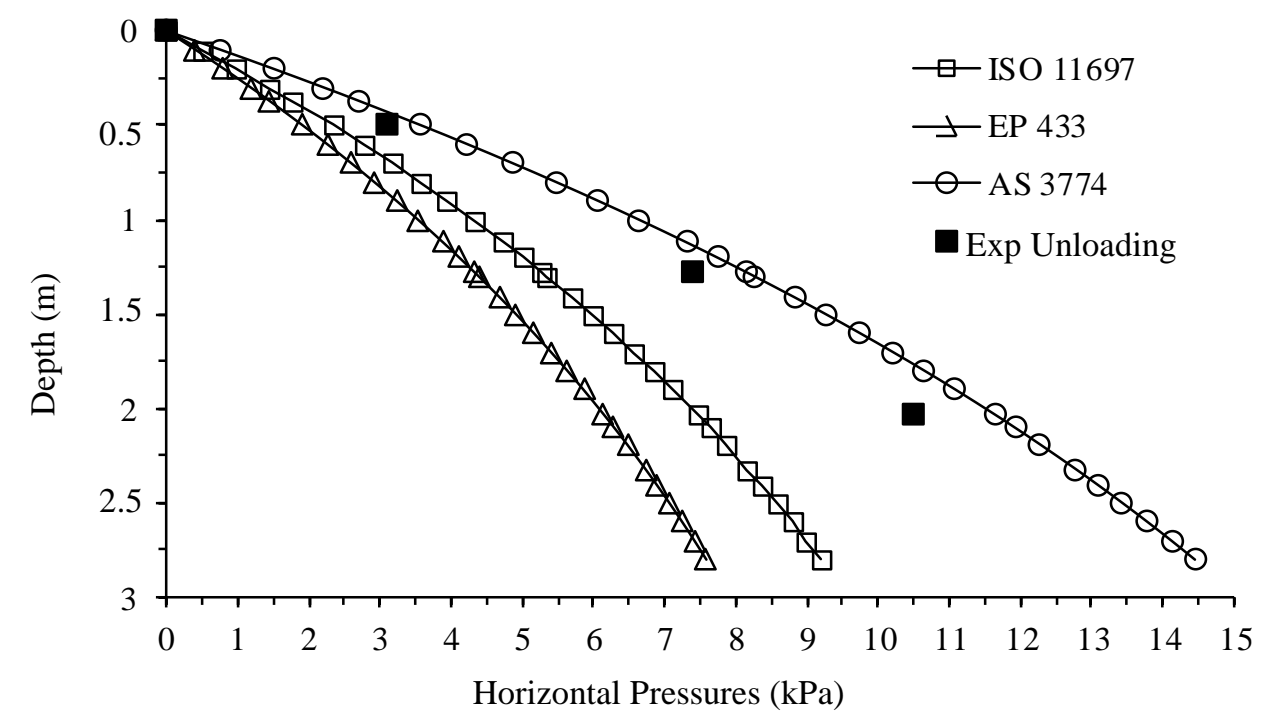

FIGURE 7. Horizontal pressures in silos with $\mathrm{H} / \mathrm{D}=1.5$ and eccentric unloading $\left(\mathrm{E}_{2}\right)$.

When the unloading of the silo started, it was observed that the grains were on mass flow and, when approaching the ratio $\mathrm{H} / \mathrm{D}=1.2$, a switching to funnel flow occurred. At this point, there was an increase of pressure due to changes in flow and this increase was added to the pressure increase already predicted due to the pressure cells that have been installed diametrically opposite to the 
unloading orifice. Thus, the experimental pressures were greater than the theoretical, demonstrating that these two effects are not perfectly considered by the standards.

Upon completion of testing, it was possible to formulate a table (Table 1) with the overpressure coefficients calculated for the H/D ratios of 1.0 and 1.5 depending on the position of the unloading orifice. Thus, it appears that the coefficients tend to increase with increasing depth of silo for the $\mathrm{H} / \mathrm{D}$ ratio equal to 1.0 . However, for the ratio $\mathrm{H} / \mathrm{D}=1.5$, the greatest differences in overpressure between the pressure sensors occurred near the CP1 due to change from mass flow to funnel flow near ratio $H / D=1.2$. As the eccentricity, it was noted that pressure differences from the loading to the unloading are greater as the unloading orifice distances from the center of the silo.

TABLE 1. Experimental overpressure coefficients in intermediate silos.

\begin{tabular}{l|l|l|l|l|l|l|l}
\hline $\mathrm{H} / \mathrm{D}=1.0$ & \multicolumn{1}{l|}{$\mathrm{H} / \mathrm{D}=1.5$} \\
\hline Pressure cells & $\mathrm{E}_{0}$ & $\mathrm{E}_{1}$ & $\mathrm{E}_{2}$ & Pressure cells & $\mathrm{E}_{0}$ & $\mathrm{E}_{1}$ & $\mathrm{E}_{2}$ \\
\hline $\mathrm{CP} 1$ & - & - & - & $\mathrm{CP} 1$ & 2.00 & 2.76 & 2.98 \\
\hline $\mathrm{CP} 2$ & 1.20 & 1.00 & 1.20 & $\mathrm{CP} 2$ & 1.72 & 2.60 & 2.96 \\
\hline $\mathrm{CP} 3$ & 1.30 & 1.50 & 1.20 & $\mathrm{CP} 3$ & 1.49 & 2.17 & 2.60 \\
\hline Mean & 1.20 & 1.20 & 1.20 & Mean & 1.7 & 2.5 & 2.8 \\
\hline
\end{tabular}

By analyzing the unloading of a metal silo into three different H/D ratios (1.0, 1.25 and 1.5) FREITAS and CALIL JÚNIOR (2005) concluded that the maximum increase in the unloading stage should be $15 \%$ of loading pressure, however the value obtained in the present study recommends an addition on unloading of 20 for the ratio $\mathrm{H} / \mathrm{D}=1$, and from 70 to $180 \%$ for the ratio $\mathrm{H} / \mathrm{D}=1.5$.

\section{CONCLUSION}

It may be concluded that:

The ISO 11697 (1995), EP 433 (2000) and AS 3774 (1996) standards overestimated the horizontal pressures of loading determined experimentally at the location point of CP3 to the ratio $\mathrm{H} / \mathrm{D}=1.0$.

$\checkmark$ The EP 433 (2000) standard was the most appropriate for the calculation of the horizontal pressures of concentric and eccentric unloading $\left(E_{2}=0.91\right)$ for the ratio $H / D=1.0$. As for the $E_{1}$ eccentricity in the same H/D ratio, ISO 11697 (1995) standard proved to be the most adequate.

$\checkmark$ For the ratio H/D $=1.5$, in both loading and unloading, the horizontal pressures were overestimated by the standards at all location points of the pressure cells with greater approximation obtained by the AS 3774 (1996) standard.

$\checkmark$ The coefficients of overpressure were affected by change from mass flow to funnel flow.

$\checkmark$ The highest mean values of overpressure coefficient were recorded for the unloading of a silo with ratio $\mathrm{H} / \mathrm{D}=1.5$ at eccentricities $\mathrm{E}_{1}$ and $\mathrm{E}_{2}$.

\section{ACKNOWLEDGEMENT}

The authors thank the National Council for Scientific and Technological Development CNPq, the Biosystem and Agricultural Department of University of Kentucky - USA, and the SILOS Research Group at UFCG for all the support given to this research. 


\section{REFERENCES}

ARTONI, R., SANTOMASO, A., CANU, P. Simulation of dense granular flows: dynamics of wall stress in silos. Chemical Engineering Science, v. 64, p. 4040 - 4050, 2009.

AS 3774. Loads on bulk containers. Sydney: Australian Standard, 1996. 78p.

DINIZ, M. J.; NASCIMENTO, J. W. B. do. Análise de pressões em silo vertical de alvenaria de tijolos. Revista Brasileira de Engenharia Agrícola e Ambiental, Campina Grande, v.10, n.1, p.212219, 2006.

EP 433. Loads exerted by free-flowing grain on bins. St. Joseph: American Society of Agricultural Engineers, 2000. 11p.

FREITAS, E. G. A.; CALIL JÚNIOR, C. Estudo teórico e experimental das pressões em silos de baixa relação altura/diâmetro e fundo plano. Cadernos de Engenharia de Estruturas, São Carlos, v. 7, n. 24, p. 1 - 34, 2005.

GALLEGO, E.; GONZÁLEZ-MONTELLANO, C.; RAMÍREZ, A.; AYUGA, F. A simplified analytical procedure for assessing the worst patch load location on circular steel silos with corrugated walls. Engineering Structures, Guildford, v. 33, p. 1940 - 1954, 2011.

ISO 11697. Bases for design of structures: loads due to bulk materials. Switzerland: International Organization for Standardization. 1995. 16p.

JULIANO, P.; MUHUNTHAN, B.; CÁNOVAS, G.V.B. Flow and shear descriptors of preconsolidated food powders. Journal of Food Engineering, Kidlington, v.72, n.2, p.157-166, 2006.

LOPES NETO, J. P. Análise teórico-experimental das forças verticais e de atrito em silos cilíndricos. 2009. 136f. Tese (Doutorado em Engenharia de Processos) - Universidade Federal de Campina Grande, Centro de Ciência e Tecnologia, Campina Grande, 2009.

LOPES NETO, J. P., NASCIMENTO, J. W. B. do; CALIL JÚNIOR, C. Análise estrutural de silos metálicos prismáticos. Ciência e Agrotecnologia, Lavras, v.32, n.4, p. 1252-1258, jul./ago. 2008.

LOPES NETO, J. P.; NASCIMENTO, J. W. B.; SILVA, V. R. Efeito do tempo de armazenagem de rações avícolas no dimensionamento de silos. Engenharia Agrícola, Jaboticabal, v.29, n.4, p.518527, out./dez. 2009a.

LOPES NETO, J. P.; SILVA, V. R.; NASCIMENTO, J. W. B. Propriedades de fluxo de produtos pulverulentos alimentícios. Revista Brasileira de Engenharia Agrícola e Ambiental, Campina Grande, v.13, n.5, p.639-644, 2009b.

MARQUES NETO, J. F. A.; SILVA, M. C. T. Aplicação da alvenaria estrutural em sistemas de armazenamento de produtos agrícolas a granel. Engenharia Agrícola, Jaboticabal, v.31, n.1, p.201210, jan./fev. 2011

MATCHETT, A. J.; O’NEILL, J. C.; SHAW, A. P. Stress distributions in 2-dimensional, wedge hoppers with circular arc stress orientation - a co-ordinate-specific Lamé-Maxwell model. Powder Technology, v. 187, p. 298 - 306, 2008.

RAMÍREZ, A.; NIELSEN, J.; AYUGA, F. On the use of plate-type normal pressure cells in silos. Part 1: Calibration and evaluation. Computers and Electronics in Agriculture, New York, v. 71, p. 71 - 76, 2010a.

RAMÍREZ, A.; NIELSEN, J.; AYUGA, F. On the use of plate-type normal pressure cells in silos. Part 2: Validation for pressure measurements. Computers and Electronics in Agriculture, New York, v. 71, p. $64-70,2010$.

RAVENET, J. Silos. Barcelona: Editores Técnicos Asociados, 1992. 508 p. 
ROTTER, J. M.; SADOWSKI, A. J. Cylindrical shell bending theory for orthotropic shells under general axisymmetric pressure distributions. Engineering Structures, Guildford, v. 42, p. 258 - 265, 2012.

SAFARIAN, S. S.; HARRIS, E. C. Design and construction of silos and bunkers. New York: Van Nostrand Reinhold Company, 1985. 468p.

VIDAL, P.; GALLEGO, E.; GUAITA, M.; AYUGA, F. Finite element analysis under different boundary conditions of the filling of cylindrical steel silos having an eccentric hopper. Journal of Constructional Steel Research, London, v. 64, 480 - 492, 2008.

WÓJCIK, M.; TEJCHMAN, J.; ENSTAD, G. G. Confined granular flow in silos with inserts Full-scale experiments. Powder Technology, Lausanne, v. 222, p. 15 - 36, 2012. 